\title{
Implications Juridical Council Regulation Honorary Center Notary Association of Indonesia Number 1 of 2017 About The Limits of Fairness Total Creation Agreement in Semarang
}

\begin{abstract}
Adwin $^{1}$, Yanto Irianto ${ }^{2}$ and Munsharif Abdul Chalim ${ }^{3}$
Abstract. The purpose of writing article is to know and the Honorary Board of Indonesian Notary Association Center for the Determination of Regulation No. 1 of 2017 on the Fairness Limit Per day Total Creation Agreement. This research methods to achieve the objectives of law is the law of sociological or empirical research. Results of the research which set the contents of regulation on the restriction of the notary in the agreement a day in which a number of 20 (twenty) in a day. Destinations create those rules for protecting Notary and society who use the services of a Notary, in case the Honorary Board of Indonesian Notary Association has authority in making these regulations mandate based on the Notary Act. Sanctions For notaries who violate these rules can be wearing the Internal sanctions in question is the organizational and External sanctions.
\end{abstract}

Keywords: Honorary Council Regulation, The Authority, Sanctions.

\section{Introduction}

Notaries are public officials appointed by the government to assist the public in making authentic act and authority governed by the Act which exist or arise in everyday life. Notary in their profession to provide public services should behave according to the rules. is important because the Notary duties of office is not solely for personal interests, but also for the benefit of society, as well as an obligation to ensure the correctness of the agreement he had done, because it is a Notary demanded more sensitive, honest, fair and transparent in making an agreement in order to ensure that all parties directly involved in the manufacture of an authentic agreement.

Notary by law is authorized to pour all agreements, agreements and determination desired by the party or parties who accidentally come before the notary for constatir description of it in an authentic act, and that the agreement that made it has the strength of evidence is complete and has validity. is confirmed in Article 1 paragraph 1 of Act No. 30 of 2004 concerning Notary, as amended by Act No. 2 of 2014 on the Amendment of Act No. 30 of 2004 concerning Notary (hereinafter written UUJN), which states that, "Notary is a public official authorized to make an authentic agreement and have more authority as referred to in Act or under any other laws". In performing its duties abatannya, a notary must fulfill all the provisions of the Notary and other regulations. Notary clerks not solely, but the notary needs to assess whether the

\footnotetext{
${ }^{1}$ Students of Master of Notary Program Faculty of Law, Universitas Islam Sultan Agung email adwindjinggo@gmail.com

2 Students of Master of Law, Faculty of Law, Universitas Islam Sultan Agung email pancaranhati.cirebon@gmail.com

${ }^{3}$ Lecturer of Faculty of Law UNISSULA
} 
desired client to be stated in an authentic agreement is not contrary to UUJN, and the rule of law. Obligation to know and understand the terms of authenticity, validity and causes nullification of a notarial agreement, it is very important to avoid preventive law Notary agreement defect that can result in loss of authenticity and the cancellation of the notarial agreement, which can be detrimental to the public interest, especially parties- interested party. however Notaries need to examine whether the desired client to be stated in an authentic agreement is not contrary to UUJN, and the rule of law. Obligation to know and understand the terms of authenticity, validity and causes nullification of a notarial agreement, it is very important to avoid preventive law Notary agreement defect that can result in loss of authenticity and the cancellation of the notarial agreement, which can be detrimental to the public interest, especially partiesinterested party. however Notaries need to examine whether the desired client to be stated in an authentic agreement is not contrary to UUJN, and the rule of law. Obligation to know and understand the terms of authenticity, validity and causes nullification of a notarial agreement, it is very important to avoid preventive law Notary agreement defect that can result in loss of authenticity and the cancellation of the notarial agreement, which can be detrimental to the public interest, especially partiesinterested party. ${ }^{4}$

Authentic agreements as proof of the strongest and most have an important role in any legal relations in society. In a variety of business relationships, activities in the fields of banking, land, social activities, and others, the need for proof in writing in the form of an authentic agreement is increasing in line with increasing demand for legal certainty in a variety of economic and social relations, both at the national, regional, and globally. Under Article 1870 Book of Civil Law (hereinafter referred to as the Civil Code) and Article 1871 of the Civil Code, "the authentic act is a tool proving perfect for both parties and their heirs as well as all those who got the rights from him about what was contained in the agreement the ".

Lately many notaries who made the agreement with the number of out of the ordinary. Coordination meeting of the Assembly of Trustees who attended the Supreme Court, Attorney General and the National Police, in which to discuss the agreement made in an amount not reasonably be considered to have / there are strong indications of a violation of office and can also be an indication of a criminal offense (Heni Kartikosari and Rusdianto Sesung, 2017 : 247). Additionally Notary get the ease and "respectful treatment" of the Government on the issue of public service. One example of the ease and honorable treatment is in terms of an agreement Fiduciary and agreements related to the Loan (KPR). The ease and respectful treatment obtained as mentioned above, a notary in front of him it is possible to make hundreds to thousands of certificates in a single day. gives rise to a presumption that the agreement does not fulfill the conditions determined in accordance with the provisions of Notary Act, namely that the agreement shall be read out.

One way to protect the office of the Notary and especially for people who use the services of a Notary associated premises of legal certainty agreement made by Notary, then the WCA Board Center Notary Association of Indonesia issued a regulation concerning the acceptable limit the number of agreement per day as outlined in Council Regulation Honor Center Indonesian Notary Association No. 1 of 2017

\footnotetext{
${ }^{4}$ Sjaifurrachman and Habib Adjie 2011 Notary Public Accountability Aspects in the Creation Deed Mandar Maju Bandung p. 121.
} 
(hereinafter referred to PDKP 1/2017). PDKP Publication of $1 / 2017$ is that these rules restrict the notary in the agreement. Deadline fairness of an agreement stipulated in Article 2, paragraph 1, which states: "Limit Fairness in agreement by the Notary as a member of the Association is 20 (twenty) certificates per day. "An agreement of Notary possible to create more than 20 (twenty) when such an agreement made a series of legal actions which require certificates that are interrelated, as stipulated in Article 2 (2) PDKP $1 / 2017$. The presence of these rules are not necessarily accepted by directly by the Notary, many pros and cons that emerged among the Notary. Based on the background that has been described on the above, the authors are interested to examine, discuss and review the above issues in the form of a thesis entitled: Implications Juridical Council Regulation Honorary Center Notary Association of Indonesia Number 1 of 2017 About the Limits of Fairness Total Creation Agreement in Semarang. as stipulated in Article 2 (2) PDKP 1/2017. The presence of these rules are not necessarily accepted by directly by the Notary, many pros and cons that emerged among the Notary. Based on the background that has been described on the above, the authors are interested to examine, discuss and review the above issues in the form of a thesis entitled: Implications Juridical Council Regulation Honorary Center Notary Association of Indonesia Number 1 of 2017 About the Limits of Fairness Total Creation Agreement in Semarang. as stipulated in Article 2 (2) PDKP 1/2017. The presence of these rules are not necessarily accepted by directly by the Notary, many pros and cons that emerged among the Notary. Based on the background that has been described on the above, the authors are interested to examine, discuss and review the above issues in the form of a thesis entitled: Implications Juridical Council Regulation Honorary Center Notary Association of Indonesia Number 1 of 2017 About the Limits of Fairness Total Creation Agreement in Semarang.

\section{Research Methods}

The method used in study is a sociological juridical approach. The research method is a sociological juridical legal research using secondary data as the data first, followed by primary data or data field, examine the effectiveness of a Law and Research wants to find a relationship (correlation) between a variety of symptoms, or variable as a means of collecting data consists of the study of documents, observation and interview. ${ }^{5}$

\section{Results And Discussion}

\subsection{The Authority of the Honorary Board of Indonesian Notary Association in Rule Making DKP No. I in 2017 on the Fairness agreement Per Day Limit}

In their duties of office Notary has the task to create authentic act for people in need, authentic agreement of Notary is a proof perfect that gave birth to a legal certainty at any time when there is a dispute between the parties that make or require the agreement. As befits a man who is not infallible and keihlafan, the Notary also human so Notaries also could have made a mistake in performing their duties and his position as a public official. Because of his job and his position as a public official authorized to make an authentic agreement.

\footnotetext{
${ }^{5}$ Soerjono Soekanto and Sri Mamuji 2001 the Normative Legal Research A Brief Overview King Grafindu Persada Jakarta p. 13.
} 
Honorary Council is one organization fittings Indonesian Notary Association (INI) and consists of 3 (three) level, which is the central, regional and local. The existence of the Council of honor stipulated in the Articles of Association . 6

The position of the Honorary Board of the Center for Notary profession system in Indonesia is an institution at the highest level in enforcing the Code of Conduct Indonesian Notary Association. Article 13 of the Code of Indonesian Notary Association noted that the Council Honorary make efforts to enforce the Notary Code. In the enforcement of the Code of Conduct Ethics Board be authorized together with the Central Board to make regulations on the enforcement of the Code. On the authority mentioned in Article 12 of the Articles of Indonesian Notary Association "Honor Council represents the Association in terms of coaching, supervision and sanctions in enforcing the Notary Code". Rulemaking carried out jointly by the Honor Council and the Center for Central Board Indonesian Notary Association.

As has been described previously that a Notary Public in implementing authority monitored externally by the Supervisory Council of Notaries and monitored internally by the Honorary Board of the Notary. ${ }^{7}$ Internal controls referred to in case was an oversight in the sphere of organization of Indonesian Notary Association emphasized that outlines the ethical oversight of the Notary through the Code of Conduct established by the Indonesian Notaries Association.

In contrast to the position of Supervisory Council of Notaries which has explicitly mentioned in UUJN, the position of the Honorary Board of the Notary is not mentioned explicitly in UUJN so as to understand the position and authority of the source of the Honorary Board of the Notary must first be constructed through Article 82 and Article 83 UUJN. In Article 82 UUJN stated that:

- Notary gathered in a single container Notary Organization.

- Notary Organization container referred to in paragraph 1 is the Indonesian Notaries Association.

- Notary organizations referred to in paragraph (1) is the only container profession Notary free and independent and established with the intent and purpose to improve the quality of the Notary profession.

- Provisions regarding the purpose, duties, authority, work procedures, and organizational structures set out in the Constitution and Bylaws of the Notary Organization.

- Provisions on the establishment, development, and supervision Notary organization governed by regulation.

In Article 1 point 5 UUJN confirmed also that the definition of Notarial Professional Organization is an organization with legal status. As an organization that incorporated the Indonesian Notary Association have Statutes and Bylaws as the constitution of the organization that determines how the organization running the Indonesian Notary Association. is in accordance with that stated in Article 82 paragraph (3) UUJN above, in the Constitution and Bylaws of the Indonesian Notary Association arranged on the purpose, duties, authority, work procedures, and organizational structures.

\footnotetext{
${ }^{6}$ Results Interview with Sugeng Budiman Notary Honorary Board Member of Semarang Regional Board Indonesian Notary Association (INI) in Semarang dated July 102018

7 Habib Adjie 2011 the Supervisory Council of Notaries As the Administrative Officer Refika Aditama Bandung p. 26.
} 
Position runs notary as a legal profession is certainly expected to have uniformity in the way of working in a professional and noble character. can be realized by the presence of a Notary standards for good behavior in the duty office and in everyday life. Of these conditions need to be established a Code of Conduct in the organization of Indonesian Notary Association.

The code of ethics is a part that can not be separated from professional organizations and almost all professional organizations have their own code of ethics. In the Indonesian Notary Association, the code of conduct in force has a different character with the code of conduct of other professional organizations for Indonesian Notary Association code of ethics explicitly mentioned in UUJN. Such provisions can be found in Article 83 UUJN which states:

- Notary organizations establish and enforce Notary Code.

- Notary organization has a copy of the register of members and submitted to the Minister and the Council of Trustees.

The provisions in Article 83 paragraph (1) of the above commands UUJN Notary organization, namely the Indonesian Notary Association to establish and enforce a code of conduct. Historically, before the code of conduct expressly commanded in UUJN, Indonesian Notary Association has had a code of ethics that was first decided in the Congress of Notaries Association of Indonesia in Surabaya in $1974 .^{8}$

Article 83 paragraph (1) of the above UUJN not only ordered the organization of Indonesian Notary Association to establish the Code but also to enforce the Code of Conduct. From the command that Act Indonesian Notary Association later formed the Council to enforce the Code of Honor Indonesian Notary Association.

From the description mentioned above it can be concluded that the source of authority of the Honorary Board of Indonesian Notary Association is obtained through delegation of UUJN to enforce the code of conduct as mandated in Article 83 paragraph (1) UUJN. Regarding the Honorary Board of the Notary authority mentioned in the Statutes, Bylaws and Code of Indonesian Notary Association. In Article 12 of the Articles of Association Indonesian Notary Association Extraordinary results Extraordinary Congress of Indonesian Notary Association Banten on 29-30 May 2015 stated:

Honorary Board has the authority to:

- perform guidance, supervision, coaching members in enforcing and upholding the Notary Code;

- examine and take a decision on the alleged violation of the Notary Code;

- provides advice and opinions to the Supervisory Council and / or the Honorary Council of the alleged violations Notary Code and Notary office;

- coordination, communication, and relates directly to members and parties related to the implementation and enforcement of Notary Code;

- Make regulations in order enforcement Notary Code together with the Central Board. "

The authority of the Honorary Board of the Notary also mentioned in Article 6 (3) of the Code Indonesian Notary Association stating that the Honor Council Center is authorized to decide and impose sanctions for violations committed by ordinary members (Notary active) Association, to the moral norms or behaviors degrading the dignity of the Notary or actions that could reduce public confidence in the Notary.

${ }^{8}$ Central Board Indonesian Notary Association 2008100 Years of Indonesian Notary Association: Self Notary Indonesia Past Present And In The Future Gramedia Pustaka Jakarta p. 198 
As the regulation serves to enforce the code of conduct then PDKP binding for all the people running the Notary office. It is based on the provisions specified in Article 3, paragraph 11 Indonesian Notary Association Code of Ethics which states "Notary and others (during the respective running Notary office) shall: Respect, adhere, implement the Regulations and Decisions Society."

\subsection{Sanctions For Rule Breaking Notary DKP No. 1 of 2017}

Violation in question is related to the formal aspect of an authentic agreement. On Article $1868 \mathrm{BW}$ has mentioned that one of the conditions the authentic act is made in the form required by the Act. Meaning "form prescribed by law" is not limited to the shape physically but it also includes ordinances making. To perfect an authentic agreement, the agreement must be read and signed by the client, two (2) witnesses and Notary. ${ }^{9}$

Regarding the reading of a liability of Notary agreement and also the formal aspects in an authentic agreement. It can be seen from the provisions of Article 16 paragraph (1) letter m UUJN which states: "(1) In carrying out his post, the Notary shall: ... m. read agreement before client in the presence of at least two (2) witnesses, or four (4) witnesses specifically for the manufacture Agreement testament under the hand, and signed on the spot by client, witnesses and Notary ". Provisions reading of the agreement by the Notary It is given little alternative, namely in Article 16 (7) UUJN which states: "The reading of the Agreement referred to in paragraph (1) letter $\mathrm{m}$ not mandatory, if client requires that the Agreement does not read because client had read his own, know, and understand its contents, provided that it is stated in the cover Agreement and on every page Minuta agreement initialed by client, witnesses and Notary Public. "However, it is limited by the provisions of Article 16 paragraph (8) UUJN which states: The provisions referred to in paragraph (7) excluded the reading head Agreement, comparison, explanation of the principal agreement briefly and clearly, as well as cover the Agreement ", so although client want to read yourself aktanya, remain the obligation of the Notary to read heads agreement and komparisi, briefly explained the contents of the agreement as well as read the concluding part agreement. Other provisions concerning the reading of the agreement is also mentioned in Article 38 paragraph (4) letter a UUJN that "End or closing the agreement contains: a. A description of the reading of the agreement ".

Reading of the agreement last provision mentioned in Article 44 paragraph (1) UUJN which states: "As soon as the agreement was read, the agreement was signed". The provision confirms that the reading of the agreement is something that must be done in making authentic act and if it is not implemented then the agreement only has the strength of evidence as the agreement under the hand just as enshrined in Article 16 (9) Jo. Article 41 Jo. Article 44 paragraph (5) UUJN. The provision confirms that the reading of the agreement is something that must be done in making authentic act and if it is not implemented then the agreement only has the strength of evidence as the agreement under the hand just as enshrined in Article 16 (9) Jo. Article 41 Jo. Article 44 paragraph (5) UUJN. The provision confirms that the reading of the agreement is something that must be done in making authentic act and if it is not implemented then

\footnotetext{
${ }^{9}$ Habib Adjie 2015 Thematic Interpretation Notary Law Indonesia: Based on Law No. 2 of 2014 on the Amendment of Act No. 30 of 2004 concerning Notary Refika Aditama Bandung p. 17-19
} 
the agreement only has the strength of evidence as the agreement under the hand just as enshrined in Article 16 (9) Jo. Article 41 Jo. Article 44 paragraph (5) UUJN.

On basis the Indonesian Notary Association Honor Council issued PDKP 1/2017 as a solution for controlling the behavior of Notaries of duty positions so as to provide legal certainty in the products it makes. Through regulation Notary expected to avoid the prohibitions mentioned in Article 4 to 16 Code of Indonesian Notary Association that a Notary Public or all the people running the Notary office banned an agreement exceeds the limits of reasonableness. These regulations once created to enforce the prohibition in the Code of Conduct. As described previously that bind Notary Code and all the people running the Notary for the oath uttered by the Notary prior stints Notary office vowing to carry out the obligations in accordance with the Code of Professional Ethics. PDKP 1/2017 constitutes an integral part of the Code of Conduct so that if a Notary violate the provisions of the 1/2017 PDKP same as violating the Notary Code and for the offense Notary be penalized.

Penalties for violating Notary 1/2017 PDKP can be either internal sanctions and external sanctions. Internal sanctions in question is organizational sanctions imposed by the Honorary Board in the form of reprimand; warning; schorsing (temporary dismissal) of the Association membership; Onzetting (dismissal) of the membership of the Association; Dishonorable discharge from the membership of the Association. ${ }^{10}$

While the external sanctions for violating Notary PDKP 1/2017 is in the form of layoffs. It is stipulated in Article 9 paragraph (1) letter d UUJN which states: "(1) Notary suspended from their posts because: ... d. Doing violation of the obligations and prohibitions Notary office and code of ethics". The above description has explained how the binding strength PDKP only $1 / 2017$ that are not internal to the organization but also well within the scope of the Act as well Organizations Indonesian Notary Association, the Indonesian Notary Association Code of Ethics and all fittings associations mentioned Indonesian Notary Association the Articles of Association of Indonesian Notary Association is an integral part of UUJN.

Regulations contained in the Per DKP No. 1 in 2017, arranged so clearly that the Notary in an agreement authentic regard to legal norms and rules that have been agreed, but seiringnya regulation goes there Notary who has violated the provisions of the regulation, which has been mmbuat authentic agreement exceeds the limits of reasonableness. Whereas according to Sasmito Raharjo, SH As well as serving as a Public Notary supervising teams of Semarang, said that in the area of the city, there are several notaries who violate the provisions to limit the number of agreement. ${ }^{11}$

\section{Closing}

\subsection{Conclusion}

Honorary Council limit the number of authorized centers Notary agreement for by Articles of Association of Indonesian Notary Association has mentioned duties and authorities of the Council of Honor is to enforce the Code of Conduct. In the Code of Conduct Indonesian Notary Association has stated that the Notary and all the people

10 Results Interview with Sugeng Budiman Notary Honorary Board Member of Semarang Regional Board Indonesian Notary Association (INI) in Semarang dated July 102018

${ }^{11}$ Interviews Sasmito Raharjo on 20 August 2018 at the office of Notary Sasmito Raharjo At 11:00 as a Member of Supervisory Council of City of Semarang. 
running the Notary is forbidden for an agreement in an amount beyond reasonable. Making the agreement in a reasonable amount is then followed up by Council Regulation Honorary Notary Association Indonesi Center No. 1 of 2017 notaries who violate Center Honor Council Regulation No. 1 of 2017 are liable to internal and external sanctions. The internal sanctions can be a reproach; warning; schorsing (temporary dismissal) of the Association membership; Onzetting (dismissal) of the membership of the Association; Dishonorable discharge from the membership of the Association. While the external sanctions is in the form of a suspension of a Notary.

\subsection{Suggestion}

Notaries are expected to work in a professional manner in order to provide legal certainty for the People who use the services. Notary agreement restriction amount by the Honor Council Regulation aims to protect the public and the Notaries themselves from the possibility of problems down the road so it is proper Notaries comply with these regulations.

\section{References}

[1] Abdul Ghofur 2009 Lembaga Kenotariatan Indonesia: Perspektif Hukum dan Etika UII Press Yogyakarta

[2] Act No. 2 of 2014 on the Amendment of Act No. 30 of 2004 on Official Notary

[3] Basic Law of the Republic of Indonesia of 1945

[4] Book of Civil Law

[5] Habib Adjie 2011 Majelis Pengawas Notaris Sebagai Pejabat Tata Usaha Negara Refika Aditama Bandung

[6] Habib Adjie 2015 Penafsiran Tematik Hukum Notaris Indonesia: Berdasarkan Undang-Undang Nomor 2 Tahun 2014 Tentang Perubahan Atas Undang-Undang Nomor 30 Tahun 2004 Tentang Jabatan Notaris Refika Aditama Bandung.

[7] Pengurus Pusat Ikatan Notaris Indonesia 2008100 Tahun Ikatan Notaris Indonesia: Jati Diri Notaris Indonesia Dulu Sekarang Dan Di Masa Datang Gramedia Pustaka Jakarta

[8] Sjaifurrachman dan Habib Adjie 2011 Aspek Pertanggungjawaban Notaris dalam Pembuatan Akta Mandar Maju Bandung.

[9] Soerjono Soekanto dan Sri Mamuji 2001 Penelitian Hukum Normatif Suatu Tinjauan Singkat Raja Grafindu Persada Jakarta 